RAUP, D. M., AND J. J. SePKoskI, JR. 1984. Periodicity of extinctions in the geologic past. Proceedings of the National Academy of Sciences of the U.S.A., 81:801-805.

SADLER, P. M. 1981. Sediment accumulation rates and the completeness of stratigraphic sections. Journal of Geology, 89:569-585.

Signor, P. W., III, AND J. H. LipPs. 1982. Sampling bias, gradual extinction patterns and catastrophes in the fossil record, p. 291-296. In, L. T. Silver and P. H. Schultz (eds.), Geological Implications of Impacts of Large Asteroids and Comets on the Earth. Geological Society of America, Special Paper 190.
Van Valen, L. M. 1984. The case against impact extinctions. Nature, 311:17-18.

Whitmire, D. P., ANd A. A. Jackson IV. 1984. Are periodic mass extinctions driven by a distant solar companion? Nature, 308:713717.

Zoller, W. H., J. R. Parrington, and J. M. Phelan Kotra. 1983. Iridium enrichment in airborne particles from Kilauea Volcano: January 1983. Science, 222:1118-1121.

ACCEPTED 12 OCTOBER 1989

\title{
ANNOUNCEMENT
}

\section{MICROFOSSIL COLLECTIONS}

A collection of over 850 species of foraminifers and ostracodes from the coastal basins of Angola has been reposited by $M$. Meijer in the Royal Museum of Central Africa, Tervuren. The collection had been used in research for oil exploration by Petrofina S. A. Other micropaleontological collections comprising material from the type Maastrichtian and from Tunesia have been reposited in the Natuurhistorisch Museum, Maastricht, Netherlands.

\section{ERRATUM}

On pages 690 and 692 of the paper "Notoschizaea Graham is a synonym of Corynepteris Bailey (Coenopteridales; Carboniferous)" by James E. Mickle (Journal of Paleontology, 63:690-693), the emended diagnosis for Corynepteris robusta (Graham, 1934) Mickle comb. nov. should read: "Anatomically preserved ovoid sporangia, about $1 \mathrm{~mm}$ long by $0.5 \mathrm{~mm}$ in diameter. Sporangial wall lacking clusters of sclereids. Sori radial, consisting of five closely appressed sessile sporangia. Involucre surrounding sorus lacking. Spores spherical, trilete, averaging $55 \mu \mathrm{m}$ in diameter, with minute coni; of the Apiculatisporis [not Apiculatisporites] type." 